\title{
Bioaccumulation Experiments in Mussels Contaminated with the Food-Borne Pathogen Arcobacter butzleri: Preliminary Data for Risk Assessment
}

\author{
Donatella Ottaviani, Serena Chierichetti, Elena Rocchegiani, Chiara Bartolini, \\ Laura Masini, Sabrina Santarelli, and Francesca Leoni \\ Istituto Zooprofilattico Umbria e Marche, Sezione di Ancona, Laboratorio Nazionale di Riferimento (LNR) Contaminazioni \\ Batteriologiche Molluschi Bivalvi Vivi, Via Cupa di Posatora 3, 60126 Ancona, Italy \\ Correspondence should be addressed to Donatella Ottaviani; d.ottaviani@izsum.it
}

Received 23 April 2013; Revised 16 July 2013; Accepted 7 August 2013

Academic Editor: Matthias Labrenz

Copyright (c) 2013 Donatella Ottaviani et al. This is an open access article distributed under the Creative Commons Attribution License, which permits unrestricted use, distribution, and reproduction in any medium, provided the original work is properly cited.

\begin{abstract}
The aim of this study was to evaluate, at a laboratory scale, the ability of this microorganism to grow in seawater and bioaccumulate in mussels (Mytilus galloprovincialis) maintained in constantly aerated tanks, containing twenty litres of artificial seawater. Three concentrations of $A$. butzleri LMG $10828^{\mathrm{T}}$ were tested (about $5 \times 10^{6} \mathrm{CFU} / \mathrm{mL}, 5 \times 10^{4} \mathrm{CFU} / \mathrm{mL}$, and $5 \times 10^{2} \mathrm{CFU} / \mathrm{mL}$ ). Following contamination, enumeration of A. butzleri was performed from water and mussels each day, for up to $96 \mathrm{~h}$. Three contamination experiments with artificial seawater in absence of mussels were also performed in the same manner. In the experiments with mussels, A. butzleri declined in water of approximately $1 \log$ every $24 \mathrm{~h}$ from the contamination. In artificial seawater without mussels the concentration of A. butzleri remained on the same logarithmic level in the first $48 \mathrm{~h}$ and then decreased of about 1 log every 24 hours. In mussels, the concentration was approximately $2 \log$ lower than the exposition level after $24 \mathrm{~h}$ from the contamination, and then it decreased exponentially of $1 \log$ every $24 \mathrm{~h}$. Our findings suggest that in the experimental conditions tested A. butzleri is neither able to effectively grow in seawater nor bioaccumulate in mussels, at least in the free and cultivable form.
\end{abstract}

\section{Introduction}

The genus Arcobacter had become increasingly important in recent years because some of the species have been considered emergent food-borne enteropathogens worldwide [1]. A. but$z$ leri is the most important and prevalent species of the genus: it has been classified as a serious hazard to human health by the International Commission on Microbiological Specifications for Foods [2] and a significant zoonotic pathogen [3]. In Europe, for example, A. butzleri has been reported as the fourth most common Campylobacter-like organism recovered from stools of patients with diarrhoea in Belgium and France $[4,5]$. Moreover, in Italy an outbreak of $A$. butzleri affected 10 children, with such severe symptoms to require hospitalization [6]. This species has also been reported to be the etiological agent of traveller's diarrhoea acquired by U.S. and European travellers to Mexico, Guatemala, and India, with a prevalence of $8 \%$ [7]. A. butzleri has also been frequently isolated from the intestinal tracts and faecal samples of different farm animals and, after excretion, this microorganism can persist in the environment [8]. In this regard, the aquatic environment is a receptacle of agricultural and urban waste water effluents and A. butzleri has been detected in coastal areas $[8,9]$. Consequently, bivalve molluscs can concentrate this microorganism from contaminated water during their filter-feeding activities $[10,11]$. Despite this, the behaviour of this pathogen in the marine environment and how it bioaccumulates in shellfish have not been investigated, although the public health risk associated with the consumption of shellfish contaminated with other human enteropathogens is well documented [12]. Based on these considerations, the aim of this work was to evaluate, at the laboratory scale, the ability of Arcobacter to grow in seawater and bioaccumulate in mussels, in order to gain preliminary information on humans risk related to the presence of $A$. butzleri in the marine environment. 


\section{Material and Methods}

2.1. Samples. Blue mussels (Mytilus galloprovincialis) of average size ( $5 \pm 7 \mathrm{~cm}$ length) were collected from an authorized harvesting area of the Central Adriatic sea (Italy), classified as category A (postharvested treatment for human consumption is not required), suitably chosen because negative for the research of Arcobacter performed monthly, in the six months previous to the execution of the described experiments. Mussels were transported to the laboratory in refrigerated containers $\left(4^{\circ} \mathrm{C}\right)$, where they were inspected. Dead or damaged specimens were eliminated. After roughly removing from the organisms the most of mud, encrustations, epiphytes, and epizoa [13], mussels were divided into aliquots of 20 elements each and closed in special mesh bags.

2.2. Bacterial Strains. The strain used for the bioaccumulation experiments was $A$. butzleri LMG $10828^{\mathrm{T}}$. This was maintained in Arcobacter broth (Oxoid) and stored at $3^{\circ} \mathrm{C} \pm$ $2^{\circ} \mathrm{C}$ for up to a week.

For the experiments A. butzleri grown in Tryptone Soy Broth (Oxoid) at $30^{\circ} \mathrm{C}$ for $48 \mathrm{~h}$ was centrifugated at $5000 \times \mathrm{g}$ for $20 \mathrm{~min}$ at $4^{\circ} \mathrm{C}$. Pellet was resuspended in phosphate buffer saline (PBS, $10 \% \mathrm{w} / \mathrm{v})$, adjusted to the concentration of $5 \times$ $10^{9} \mathrm{CFU} / \mathrm{mL}$ after optical measurement $\left(1 \times 10^{8} \mathrm{CFU} / \mathrm{mL}\right.$ gave ca. $0.1 \mathrm{OD} 600 \mathrm{~nm})$, and then stored at $3^{\circ} \mathrm{C} \pm 2^{\circ} \mathrm{C}$ for up to 1 hour before use.

2.3. Acclimation of the Mussels. Prior to each experiment, 20 mussels were evenly distributed into each of four tanks containing 20 liters of artificial seawater (Instant Ocean Aquarium Systems), approximately $1 \mathrm{~L}$ of water per mussel. The conditions in the tanks were the following: salinity, 2.8-3.3\%; temperature, $16-18^{\circ} \mathrm{C}$, and constant aeration [13]. At time $0 \mathrm{~h}$, a ration of Instant Algae Shellfish Diet 1800 (Reed Mariculture, Campbell, CA), consisting of four inactivated algae (Isochrysis, Pavlova, Thalassiosira weissflogii, and Tetraselmis), was added to each tank, at the rate of $1 \times$ $10^{6}$ algae/mL of seawater [14]. Mussels were first allowed to adapt for $24 \mathrm{~h}[13,14]$; then, after visually assessing that they were alive, the four tanks were randomly assigned to the negative-control (no A. butzleri added) or one of the three test groups. Mussel-feeding was repeated at the same rate at $24 \mathrm{~h}$ and then reduced to $5 \times 10^{5}, 5 \times 10^{4}, 5 \times 10^{3}$ algae $/ \mathrm{mL}$ of water at 48,72 , and $96 \mathrm{~h}$, respectively, since a portion of the organisms had been removed for daily testing [14].

2.4. Bioaccumulation Experiments. $200 \mathrm{~mL}$ of PBS containing about $5 \times 10^{8}, 5 \times 10^{6}$, and $5 \times 10^{4} \mathrm{CFU} / \mathrm{mL}$ of $A$. butzleri LMG $10828^{\mathrm{T}}$ were inoculated in the tank of the first, second, and third test groups, respectively, to achieve the final concentrations of about $5 \times 10^{6} \mathrm{CFU} / \mathrm{mL}, 5 \times 10^{4} \mathrm{CFU} / \mathrm{mL}$, and $5 \times 10^{2} \mathrm{CFU} / \mathrm{mL}$. Immediately after the experimental contamination, $10 \mathrm{~mL}$ of water from each tank were collected, in order to determine the concentration of A. butzleri. Then, the enumeration of $A$. butzleri was performed each day for all the test groups and the negative control from both water and mussels, for up to $96 \mathrm{~h}$. Three other test groups represented by tanks containing $20 \mathrm{~L}$ of artificial seawater without mussels and aeration were contaminated and daily analyzed in the same manner as the water in the experiments with mussels.

2.5. Preparation of the Samples. After having carefully cleaned externally the organisms and eliminated the residual traces of mud, encrustations, epiphytes, and epizoa, mussels were aseptically prepared for analysis in accordance with a standard procedure [15]. For each sample, constituted by 5 elements [14], $10 \mathrm{~g}$ of digestive tissues (DT) and $10 \mathrm{~g}$ of the remaining part of the body, including the liquor (BL), were collected separately, diluted $1: 10$ with $0.1 \%$ peptone $(\mathrm{w} / \mathrm{v})$ $0.85 \%$ salt $(\mathrm{w} / \mathrm{v})$ water, and homogenized in a blender.

2.6. Enumeration of A. butzleri. Both water and mussel homogenates were subjected to serial dilutions using the same buffer to as high as $10^{-6}$ and $A$. butzleri was enumerated using a conventional pour plate method, inoculating $10 \mathrm{~mL}$ of each dilution on three plates $(3 \mathrm{~mL}, 3 \mathrm{~mL}$, and $4 \mathrm{~mL}$ for each plate) of Trypticase Soy Agar (Oxoid) plus 5\% sheep blood $[8,16]$. After incubation at $30^{\circ} \mathrm{C}$ for $48 \mathrm{~h}$, typical colonies were counted.

In this medium typical colonies were small, colorless or beige to off-white translucent, and of 1 to $4 \mathrm{~mm}$ in diameter [8, 16]. Presumptive Arcobacter colonies were confirmed with Gram stain (Gram negative, curved, or slightly curved rod) and oxidase test (positive). The definitive identification of the species was performed by PCR of the rpoB gene [16]. Genotyping by ERIC-PCR [17] was also performed to verify that the isolates belonged to the type strain used for contamination.

2.7. Statistical Analysis. Three independent experiments were performed for mussels collected at different times from each of the test group and for artificial seawater from both the experiments with and without mussels. Each analysis was performed by analyzing water, DT, and BL for three times. For each test group mean values $(n=9)$ and standard deviations were calculated. The Student's $t$-test was used to compare the means of the bacterial counts obtained from DT and BL for each level of experimental contamination and a probability value $(P)<0.05$ was regarded as statistically significant.

\section{Results and Discussion}

In each experiment, the uncontaminated mussels used as negative controls always resulted negative for $A$. butzleri (data not shown). Microbiological trends of A. butzleri in experimentally contaminated mussels and water are shown in Figures 1-4. In the experiments without the mussels the concentration of $A$. butzleri in water decreased less than $0.5 \mathrm{log}$ every $24 \mathrm{~h}$ in the first $48 \mathrm{~h}$, and then decreased of about $1 \mathrm{log}$ every 24 hours (Figure 1). In the experiments with mussels, A. butzleri declined in water exponentially over time, with a reduction of about $1 \log$ every $24 \mathrm{~h}$ (Figure 2 ). The greater reduction in the first $48 \mathrm{~h}$ of the loads of $A$. butzleri in the tests conducted in the water with mussels than in those without the mussels can be probably attributed to the presence of 


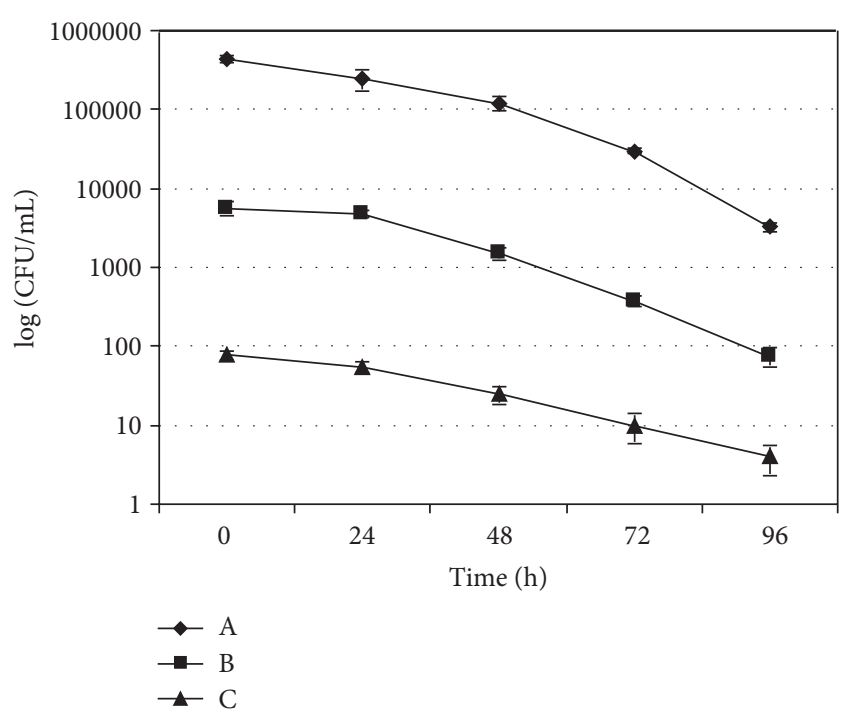

Figure 1: Comparison of level of A. butzleri LMG $10828^{\mathrm{T}}$ in water without mussels at time 0 and at $24,48,72$, and $96 \mathrm{~h}$ after contamination with about $5 \times 10^{6} \mathrm{CFU} / \mathrm{mL}(\mathrm{A}), 5 \times 10^{4} \mathrm{CFU} / \mathrm{mL}$ (B), and $5 \times 10^{2} \mathrm{CFU} / \mathrm{mL}(\mathrm{C})$. The error bars indicate the standard deviation of three independent experiments each performed in triplicate $(n=9)$.

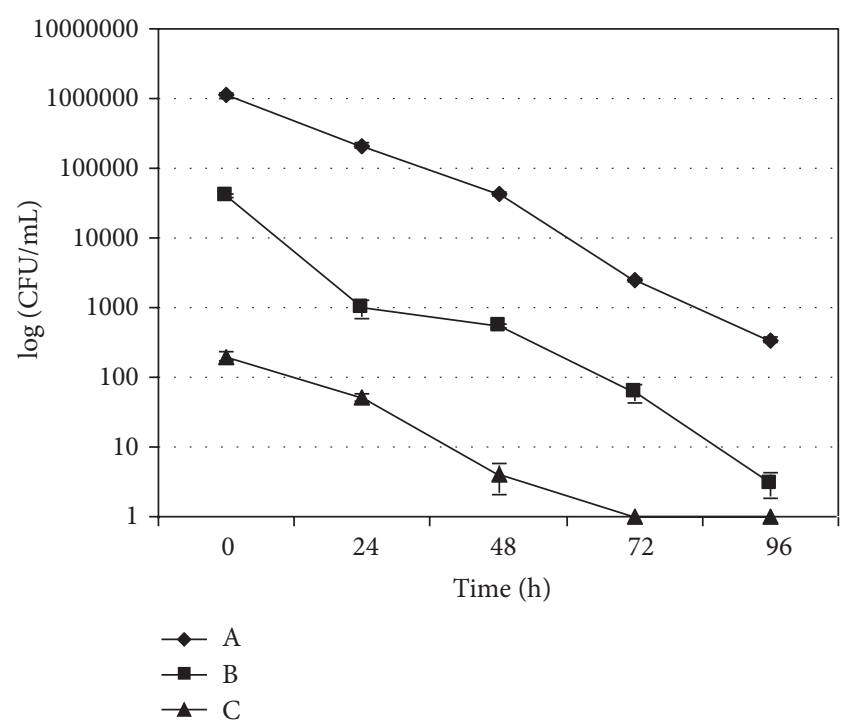

FIGURE 2: Comparison of level of A. butzleri LMG $10828^{\mathrm{T}}$ in water with mussels at time 0 and at 24,48,72, and $96 \mathrm{~h}$ after contamination with about $5 \times 10^{6} \mathrm{CFU} / \mathrm{mL}(\mathrm{A}), 5 \times 10^{4} \mathrm{CFU} / \mathrm{mL}(\mathrm{B})$, and $5 \times$ $10^{2} \mathrm{CFU} / \mathrm{mL}(\mathrm{C})$. The error bars indicate the standard deviation of three independent experiments each performed in triplicate $(n=9)$.

the animals and their capacity to filter the microorganism from the water. In the contamination experiments with about $5 \times 10^{2} \mathrm{CFU} / \mathrm{mL}$, A. butzleri was no more detectable after $72 \mathrm{~h}$ from the contamination in the water with mussels (Figure 2). Considering instead the microbiological trend of $A$. butzleri in mussels, for all levels of the experimental contamination tested, the counts obtained from DT were not

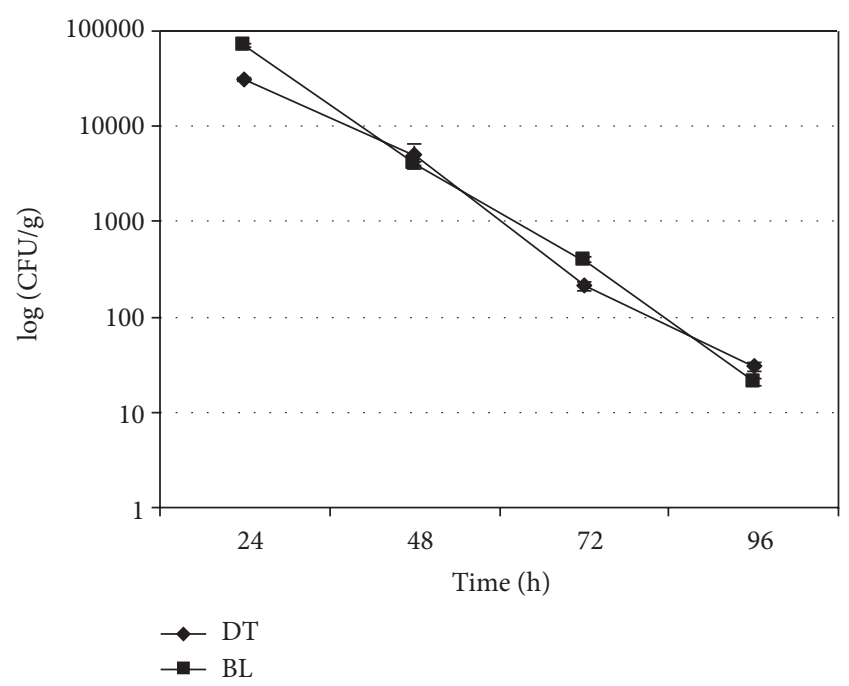

Figure 3: Comparison of level of A. butzleri LMG $10828^{\mathrm{T}}$ in digestive tissue (DT) and in the remaining body and liquor (BL) of mussels at $24,48,72$, and $96 \mathrm{~h}$ after water contamination with about $5 \times 10^{6} \mathrm{CFU} / \mathrm{mL}$. The error bars indicate the standard deviation of three independent experiments each performed in triplicate $(n=9)$.

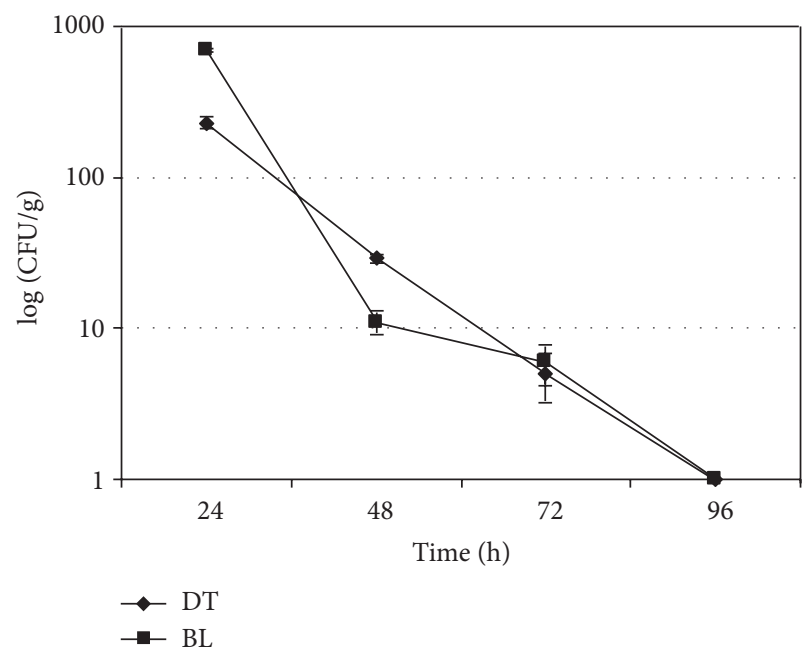

FIgURE 4: Comparison of level of A. butzleri LMG $10828^{\mathrm{T}}$ in digestive tissue (DT) and in the remaining body and liquor (BL) of mussels at 24, 48, 72, and $96 \mathrm{~h}$ after water contamination with about $5 \times 10^{4} \mathrm{CFU} / \mathrm{mL}$. The error bars indicate the standard deviation of three independent experiments each performed in triplicate $(n=9)$.

statistically different from those obtained from BL (Figures 3 and 4). This suggests that, unlike other pathogens [18], for $A$. butzleri DT does not represent an elective tissue for bioaccumulation. After $24 \mathrm{~h}$ from the contamination, the concentration of $A$. butzleri in the mussels was approximately $2 \log$ lower than the concentration in water at the time 0 ; then it decreased exponentially of about 1 log every $24 \mathrm{~h}$ (Figures 2,3 , and 4). In the bioaccumulation test with a level of water contamination of about $5 \times 10^{2} \mathrm{CFU} / \mathrm{mL}, A$. butzleri was not detectable in mussels at $24 \mathrm{~h}$ from contamination, remaining not detectable after 48,72 , and $96 \mathrm{~h}$ (data not shown). 
Fecally contaminated water and food products (especially poultry and red meat, milk, and shellfish, which had been often shown to be contaminated with arcobacters) have been suggested as the transmission routes for A. butzleri [1]. It was also hypothesized that clinical relevant Arcobacter species could be autochthonous to marine environments [9]. Previous studies reported a high prevalence of this pathogen in faeces of livestock animals [19] and in farm effluents [20] and this finding could indicate that those are the real sources of surface water contamination. Moreover, A. butzleri is significantly more prevalent in water that is fecally contaminated than in water that is not [8]. Based on these pieces of evidence, we also believe that this species arrives in seawater through polluted fresh water. Moreover, our results, obtained at laboratory scale, suggest that $A$. butzleri is not able to effectively grow in seawater in free and cultivable form. Of course we can not exclude the possibility that this organism in marine environment may instead find suitable conditions for the survival and rooting, adhering to zooplankton as previously suggested $[9,21]$. The observed differences in clearance of bioaccumulated bacteria and viruses raise questions about potential interactions between shellfish and human pathogens [18]. For Norovirus, for example, bioaccumulation specifically occurred in digestive tissues by binding to specific ligands [18]. For other enteropathogens as Salmonella their capability of long-term persistence within shellfish through an unusual mechanism of colonization has been demonstrated [22, 23]. Although species like A. mytili and A. molluscorum can be commonly found in mussels $[1,16]$, our trends of the microbial counts of A. butzleri in both $\mathrm{DT}$ and BL suggest that this species, or at least the type strain, is neither able to effectively bioaccumulate in mussels nor to grow at cultivable form within these organisms for over than 96 hours after the experimental contamination.

\section{Conclusions}

The significance of A. butzleri as a human pathogen is not fully understood at the present, although, considering its isolation in cases of human and animal illness and from foods of animal origin, it may certainly be added to the ranks of emerging food-borne pathogens. For this reason, it is necessary to acquire more information on its epidemiology, occurrence in food, and survival strategies in the aquatic environment.

We are aware of the limitations of this study, where only the type strain, that is not of marine origin, has been tested. Furthermore in vitro experiments may not represent what occurs in the natural environment. For these reasons, it is our intention to continue investigating this specific field, to get supplementary data by performing experiments with different shellfish and strains of $A$. butzleri.

To our knowledge, this is the first study which tested, at a laboratory scale, the performances of A. butzleri to grow in seawater and bioaccumulate in mussels, providing preliminary information on risk linked to the presence of this pathogen in marine organisms which are also food for humans.

\section{Acknowledgment}

This work was funded by a Research Project (IZSUM 10/2011) of the Italian Ministry of Health.

\section{References}

[1] L. Collado and M. J. Figueras, “Taxonomy, epidemiology, and clinical relevance of the genus Arcobacter," Clinical Microbiology Reviews, vol. 24, no. 1, pp. 174-192, 2011.

[2] ICMSF, Microorganisms in Foods. Microbiological Testing in Food Safety Management. International Commition on Microbiological Specifications for Foods, Kluwer Academic/Plenum, New York, NY, USA, 2002.

[3] S. Cardoen, X. van Huffel, D. Berkvens et al., "Evidence-based semiquantitative methodology for prioritization of foodborne zoonoses," Foodborne Pathogens and Disease, vol. 6, no. 9, pp. 1083-1096, 2009.

[4] V. Prouzet-Mauléon, L. Labadi, N. Bouges, A. Ménard, and F. Mégraud, "Arcobacter butzleri: underestimated enteropathogen," Emerging Infectious Diseases, vol. 12, no. 2, pp. 307-309, 2006.

[5] O. Vandenberg, A. Dediste, K. Houf et al., “Arcobacter species in humans," Emerging Infectious Diseases, vol. 10, no. 10, pp. 18631867, 2004.

[6] P. Vandamme, P. Pugina, G. Benzi et al., "Outbreak of recurrent abdominal cramps associated with Arcobacter butzleri in an Italian school," Journal of Clinical Microbiology, vol. 30, no. 9, pp. 2335-2337, 1992.

[7] Z.-D. Jiang, H. L. Dupont, E. L. Brown et al., "Microbial etiology of travelers' diarrhea in Mexico, Guatemala, and India: importance of enterotoxigenic bacteroides fragilis and Arcobacter species," Journal of Clinical Microbiology, vol. 48, no. 4, pp. 1417-1419, 2010.

[8] L. Collado, I. Inza, J. Guarro, and M. J. Figueras, "Presence of Arcobacter spp. in environmental waters correlates with high levels of fecal pollution," Environmental Microbiology, vol. 10, no. 6, pp. 1635-1640, 2008.

[9] M. T. Fera, T. L. Maugeri, C. Gugliandolo et al., "Detection of Arcobacter spp. in the coastal environment of the Mediterranean Sea," Applied and Environmental Microbiology, vol. 70, no. 3, pp. 1271-1276, 2004.

[10] L. Collado, J. Guarro, and M. J. Figueras, "Prevalence of Arcobacter spp. in meat and shellfish," Journal of Food Protection, vol. 72, pp. 1002-1006, 2009.

[11] T. L. Maugeri, C. Gugliandolo, M. Carbone, D. Caccamo, and M. T. Fera, "Isolation of Arcobacter spp. from brackish environment," New Miocrobiology, vol. 23, pp. 143-149, 2000.

[12] I. Potasman, A. Paz, and M. Odeh, "Infectious outbreaks associated with bivalve shellfish consumption: a worldwide perspective," Clinical Infectious Diseases, vol. 35, no. 8, pp. 921928, 2002.

[13] L. Croci, E. Suffredini, L. Cozzi, and L. Toti, "Effects of depuration of molluscs experimentally contaminated with Escherichia coli, Vibrio cholerae $\mathrm{O} 1$ and Vibrio parahaemolyticus," Journal of Applied Microbiology, vol. 92, no. 3, pp. 460-465, 2002.

[14] G. P. Richards, J. P. Fay, K. A. Dickens, M. A. Parent, D. S. Soroka, and E. F. Boyd, "Predatory bacteria as natural modulators of Vibrio parahaemolyticus and Vibrio vulnificus in seawater and oysters," Applied and Environmental Microbiology, vol. 78, no. 20, pp. 7455-7466, 2012. 
[15] UNI EN ISO 6887-3, "Microbiology of food and animal feeding stuffs-preparation of test samples, initial suspension and decimal dilutions for microbiological examination," in Annual Report 2003, 2003, International Organization for Standardization.

[16] L. Collado, I. Cleenwerck, S. van Trappen, P. de Vos, and M. J. Figueras, "Arcobacter mytili sp. nov., an indoxyl acetatehydrolysis-negative bacterium isolated from mussels," International Journal of Systematic and Evolutionary Microbiology, vol. 59, no. 6, pp. 1391-1396, 2009.

[17] K. Houf, L. De Zutter, J. Van Hoof, and P. Vandamme, "Assessment of the genetic diversity among Arcobacters isolated from poultry products by using two PCR-based typing methods," Applied and Environmental Microbiology, vol. 68, pp. 2172-2178, 2002.

[18] H. Maalouf, J. Schaeffer, S. Parnaudeau et al., "Strain-dependent norovirus bioaccumulation in oysters," Applied and Environmental Microbiology, vol. 77, no. 10, pp. 3189-3196, 2011.

[19] E. van Driessche, K. Houf, J. van Hoof, L. de Zutter, and P. Vandamme, "Isolation of Arcobacter species from animal feces," FEMS Microbiology Letters, vol. 229, no. 2, pp. 243-248, 2003.

[20] H. N. Chinivasagam, B. G. Corney, L. L. Wright, I. S. Diallo, and P. J. Blackall, "Detection of Arcobacter spp. in piggery effluent and effluent-irrigated soils in Southeast Queensland," Journal of Applied Microbiology, vol. 103, no. 2, pp. 418-426, 2007.

[21] C. Gugliandolo, G. P. Irrera, V. Lentini, and T. L. Maugeri, "Pathogenic Vibrio, Aeromonas and Arcobacter spp. associated with copepods in the Straits of Messina (Italy)," Marine Pollution Bulletin, vol. 56, no. 3, pp. 600-606, 2008.

[22] C. M. Morrison, S. M. Dial, W. A. Day, and L. A. Joens, "Investigations of Salmonella enterica serovar newport infections of oysters by using immunohistochemistry and knockout mutagenesis," Applied and Environmental Microbiology, vol. 78, no. 8, pp. 2867-2873, 2013.

[23] C. M. Morrison, A. E. Armstrong, S. Evans, R. M. Mild, C. J. Langdon, and L. A. Joens, "Survival of Salmonella newport in oysters," International Journal of Food Microbiology, vol. 148, no. 2, pp. 93-98, 2011. 

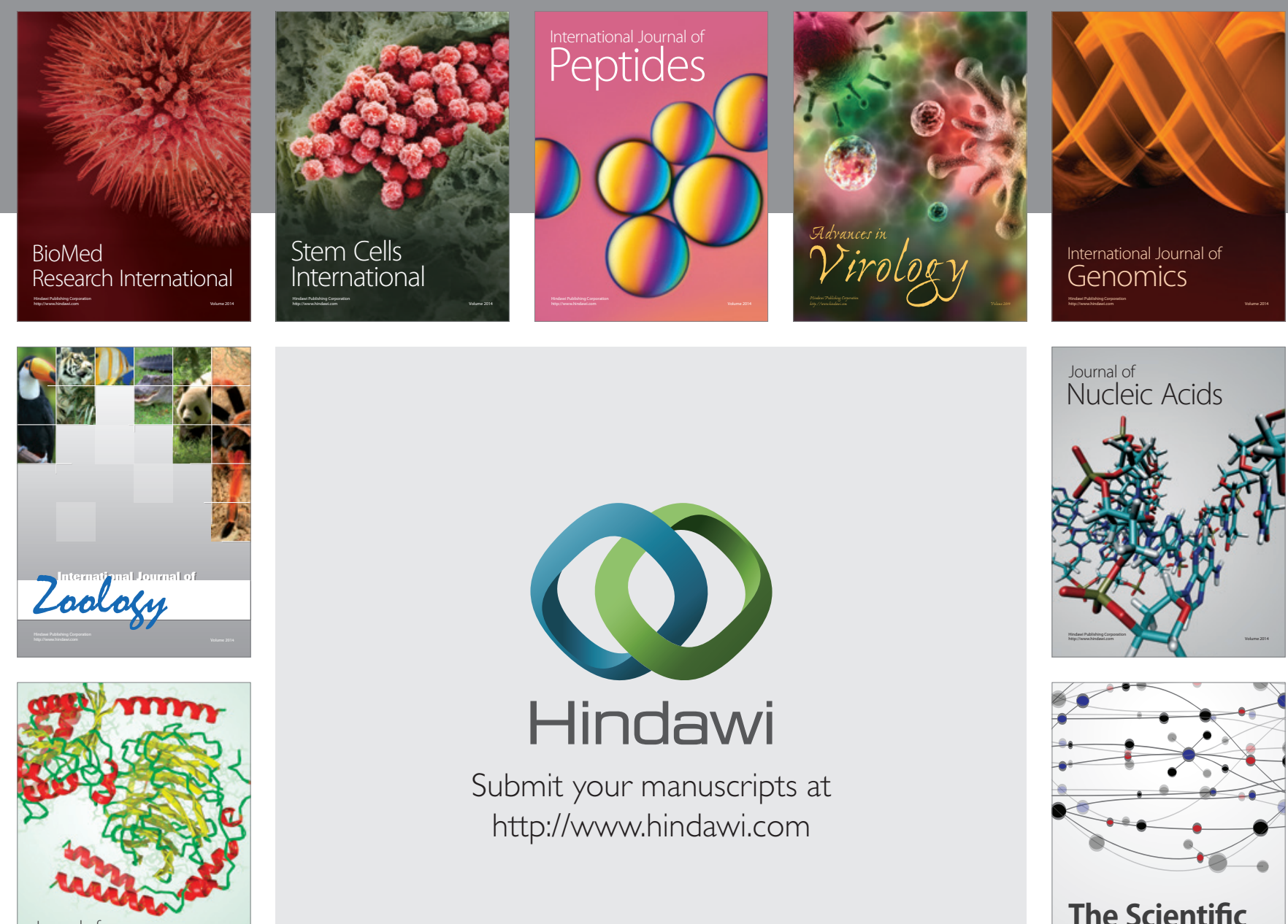

Submit your manuscripts at

http://www.hindawi.com

Journal of
Signal Transduction
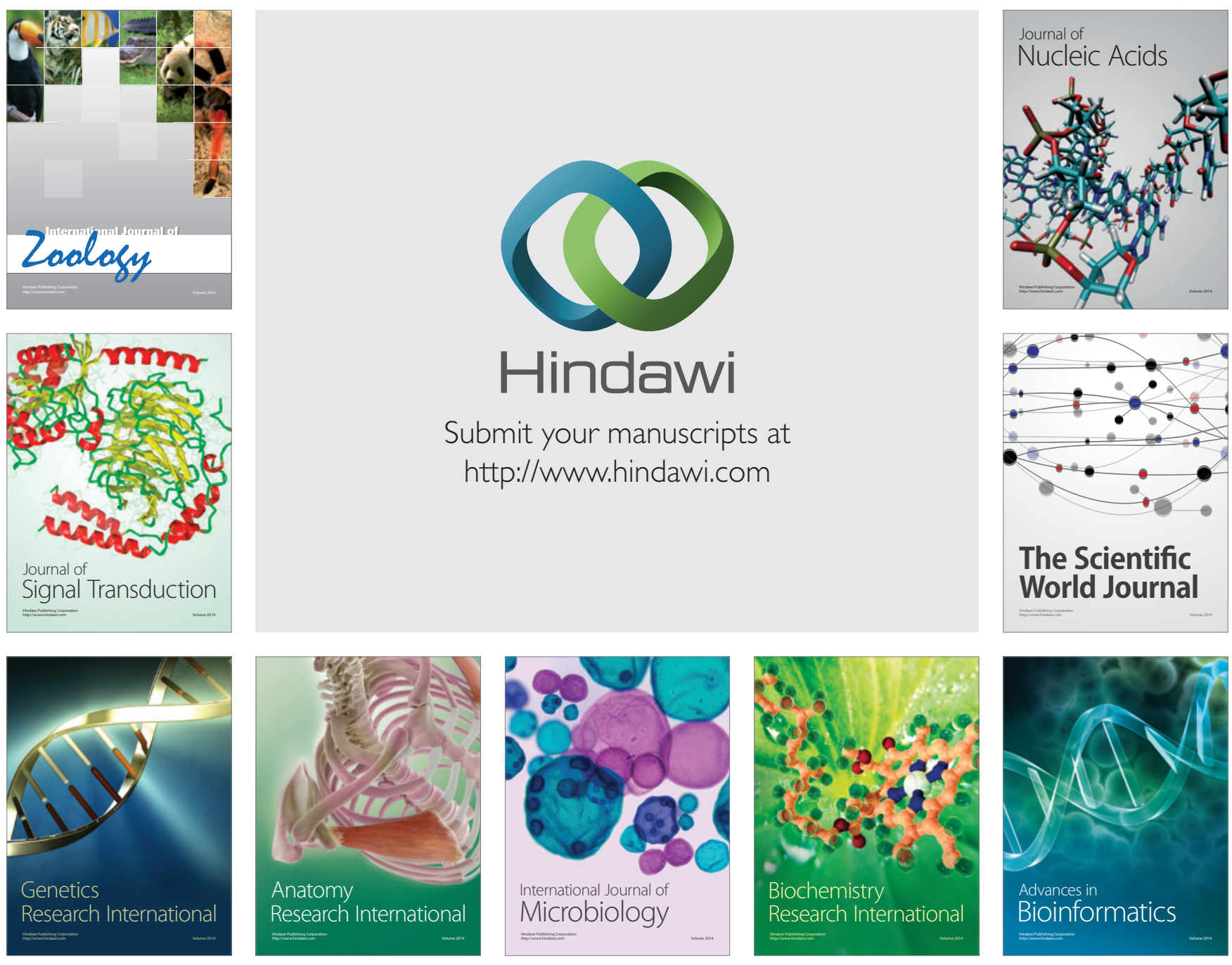

The Scientific World Journal
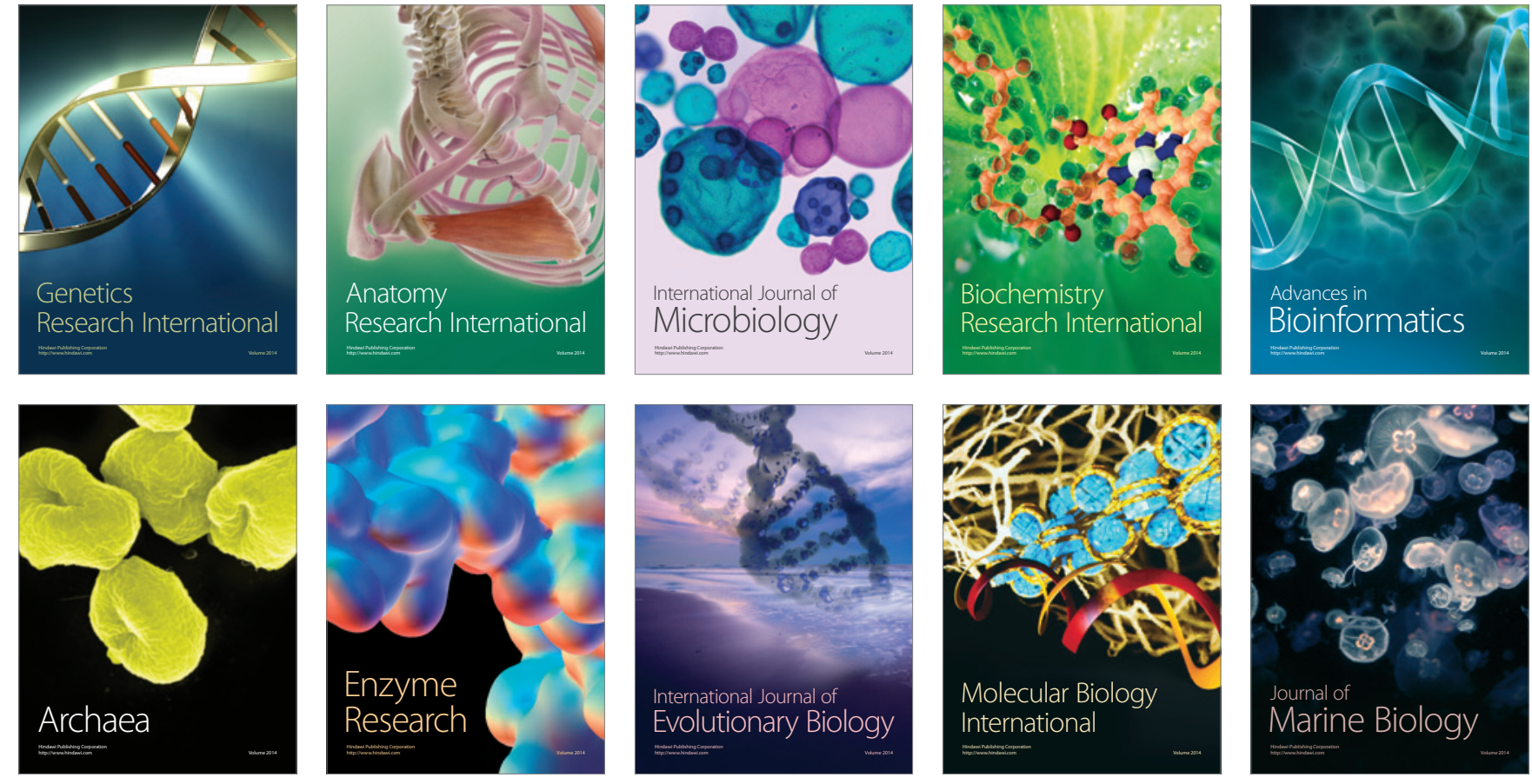